\title{
Mentha Piperita Extract as a Natural Product for the Corrosion Inhibition of Low Carbon Steel in a Polluted NaCl Environment: Chemical, Electrochemical and Biological Studies
}

Prof. Abd El-Aziz S. Fouda ( $\square$ asfouda@hotmail.com )

Mansoura University

Ameena M. Al-Bonayan

Umm al-Qura University

Dalia M. Eid

Qatar University

\section{Research Article}

Keywords: Mentha Piperita Extract (MPE), low carbon steel (LCS), Polluted NaCl Environment, protection efficiency (PE)

Posted Date: December 22nd, 2021

DOI: https://doi.org/10.21203/rs.3.rs-1106403/v1

License: (c) (1) This work is licensed under a Creative Commons Attribution 4.0 International License.

Read Full License 


\title{
Mentha Piperita Extract as a Natural Product for the Corrosion Inhibition of Low Carbon Steel in a Polluted NaCl Environment: Chemical, Electrochemical and Biological Studies
}

\author{
Abd El-Aziz S. Fouda*a ${ }^{*}$ Ameena M. Al-Bonayan ${ }^{\text {b }}$, Dalia M. Eid ${ }^{\text {c }}$ \\ $\mathrm{a}^{*}$ Department of Chemistry, Faculty of Science, El-Mansoura University, El-Mansoura-35516, Egypt, Fax: \\ +20502202264, Tel:+2 0502365730 \\ ${ }^{\mathrm{b}}$ Chemistry Department, Faculty of Science, Umm Al-Qura University, Makkah, KSA \\ ${ }^{c}$ Nuclear Materials Authority, Egypt, and TA at Qatar University, Doha p.o.2713, Qatar \\ "Submitting by: Prof. Abd El-Aziz S. Fouda (asfouda@ hotmail.com)
}

\begin{abstract}
The impact of aqueous Mentha Piperita Extract (MPE) as a corrosion inhibitor for low carbon steel (LCS) in $\mathrm{NaCl} / \mathrm{Na}_{2} \mathrm{~S}$ solution was investigated using chemical and electrochemical techniques to evaluate the protection performance of MPE. "As the concentration of the extract increased, the protection efficiency (PE) increased, reaching $91.2 \%$ at $300 \mathrm{ppm}$, whereas the increase in temperature favored to slow decrease". The extract was physically adsorbed on the metal surface according to the Temkin isotherm. Polarization data revealed that this extract acts as a mixed inhibitor. The mechanism of corrosion protection of MPE was discussed from electrochemical techniques. MPE was adsorbed on LCS obeying Temkin isotherm. Surface morphology techniques such as scanning electron microscopy (SEM) and atomic force microscopy (AFM) were used to demonstrate the creation of a protective coating on the LCS in the presence of MPE. The extract inhibits the bacterial activity of Escherichia coli.
\end{abstract}

\section{Introduction}

Because of its low cost, low carbon steel (LCS) appears to be widely employed for structural purposes. However, its susceptibility to rusting in humid air and rapid dissolution rate in acidic solutions are significant drawbacks for its application on a broader scale without protection. "Corrosion is a naturally occurring phenomenon that deteriorates a material or its properties because of a reaction with its environment. Corrosion can cause dangerous and expensive damage to everything from pipelines, bridges and public buildings to vehicles, water, and wastewater systems, and even home appliances. It is one of the most serious problems in the oil and gas industry. In general, hydrochloric acid is employed in industries for cleaning, descaling, and pickling steel structures such as reactors, agitators, pumps, drains, and so on, which are prone to significant metal dissolution. The use of inhibitors is the most feasible corrosion prevention approach for slowing down the aggressiveness of this acid. The use of organic extracts is one of the most widely practical methods for protection of metals and alloys against corrosion, since adding extracts does not cause disruption of the industrial process". In previous years, numerous extracts have been extracted or selected from existing plants, and it has been found that the finest extracts are those having a center for $\pi$ electron donation (usually heightened by the presence of heteroatoms in aromatic compounds), while others may be obtained from extracts of obviously occurring compounds ${ }^{1-3}$. Extracts derived from plants are significant because they are environmentally friendly ${ }^{4,5}$, nontoxic and do not contain heavy metals. "It has been established that sulfur and/or nitrogen containing heterocyclic compounds with various substituents are effective corrosion extracts in different solutions over a wide $\mathrm{pH}$ range. The PE of an organic compound mainly depends on its ability to adsorb on the metal surface". The protective nature of the adsorbed compact barrier film is influenced by the nature of the metal surface and electronic structure of inhibiting molecules. The adsorption of nitrogenous compounds is ascribed to the effects of the functional groups connected with aromatic rings parallel to the metal surface $^{6}$. Indeed, various investigations on corrosion inhibition utilizing plant extract ${ }^{7-9}$, pure chemicals ${ }^{10,11}$ and essential oils ${ }^{12-21}$ have been performed in the last decade. They have all been identified as excellent inhibitors for various metals and alloys in various acidic settings. The current study aims to evaluate the protection efficiency (PE) of the investigated MPEM in directing the corrosion of LCS in polluted $\mathrm{NaCl}$ and to analyze the protective film formed on the LCS surface using scanning electron 
microscopy (ESM), energy dispersive X-ray (EDX) and AFM techniques. Finally, the extract's bacterial activity against Escherichia coli was investigated.

\section{Experimental}

Materials and solutions. The material used is LCS, which has the following chemical conformation (weight \%): $0.014 \mathrm{C}, 0.004 \mathrm{Si}, 0.36 \mathrm{Mn}, 0.25 \mathrm{P}$ and the rest is iron.

Preparation of the extract. The origins of Mentha Piperita are assumed to be in Northern Africa and the Mediterranean. Mint is cited as a stomach pain reliever in the Ebbers Papyrus, an ancient Egyptian medical document dating from 1550 BC. In Egypt, the mint was so valuable that it was utilized as a type of currency".

An aqueous extract of MPE was prepared by powdering a reasonable number of plant leaves to get $500 \mathrm{~g}$ of powdered materials. These quantities were soxholated with double distilled water, dried until frozen, weighed, and stored at ${ }^{\circ} \mathrm{C}$ until needed. The 3.5 percent $\mathrm{NaCl}$ and $16 \mathrm{ppm} \mathrm{Na}_{2} \mathrm{~S}$ solutions were created by liquefying the appropriate quantity of salts in double distilled water. All the compounds were of the AR grade. The studies were performed in settings that were naturally non bubbling and stagnant. The addition of extract had no effect on the $\mathrm{pH}$ of the medium.

Permission: There is no permission for collecting the Mentha Piperita plant from Mansoura City; Dr. Ashraf Nofal associate prof. of Fungi and Plant Pathology, Environmental Studies and Research Institute, University of Sadat City, who is collected the plant from Mansoura, Egypt, for student and research". We confirm that the collection of plant material was complied with relevant institutional, national, and international guidelines and legislation.

Preparation of bacterial agriculture media. Dissolve $50 \mathrm{~g}$ of the medium in 1 of double distilled water by heating. Sterilize for 15 minutes in an autoclave at $121^{\circ} \mathrm{C}$. Cool to $45-50^{\circ} \mathrm{C}$ and then thoroughly combine and distribute into plates. Allow the plates to harden. The temperature of the prepared medium should be between 8 and 15 degrees Celsius. Violet red is the color. The results of chemical tests in the literature with aqueous extract of MPE contain phytochemicals such as diterpenes, steroids, tannin, flavonoids, carbohydrates, alkaloids, phenols, coumarin, and saponins, whereas the ethanolic extract also contains the same chemicals except tannin, cardiac glycosides, and saponin ${ }^{22,23}$.

Methods. The weight loss approach is well known as the most extensively used methodology for assessing inhibition effectiveness. The procedure for WL determination was similar to that reported earlier $^{24}$. Seven samples of LCS $(2 \times 2 \times 0.1 \mathrm{~cm}$ as a dimension) were reweighed using a digital balance (Model Denver Instrument) and dipped in $100 \mathrm{ml}$ of corroding medium (in open beakers) with and without different concentrations $(50-300 \mathrm{ppm})$ of the extract at temperatures from $25-40^{\circ} \mathrm{C}$ for a total period of $180 \mathrm{~min}$ dipped period. The samples were withdrawn from the solution at intervals of $30 \mathrm{~min}$ immersion, rinsed with water, scrubbed with a bristle brush under running water, dried and reweighed". Triplicate experiments were set up for each concentration of extract for reliability.

"Cathodic and anodic polarization curves were recorded in the potential region OCP $\pm 250 \mathrm{mV}$ (SCE) as a function of concentration at a sweep rate of $0.2 \mathrm{mV} / \mathrm{s}$. A cell with three electrodes was used. LCS as the working electrode, reference electrode was saturated calomel electrode (SCE) and counter electrode was Pt foil". From PP curves, corrosion data such as $E_{\text {corr }}$, corrosion current $i_{\text {corr }}$, anodic Tafel slopes, $\beta_{\mathrm{a}}$ and cathodic slopes $\beta_{\mathrm{c}}$ were computed.

EIS spectra were recorded in the frequency ranges $105 \mathrm{~Hz}$ and $0.1 \mathrm{~Hz}$ with amplitude of $10 \mathrm{mV}$ peak to peak at the open-circuit potential. The values of charge transfer resistance $\left(R_{c t}\right)$ and double layer capacitance $\left(\mathrm{C}_{\mathrm{dl}}\right)$ were calculated.

The EFM was carried out at two different frequencies: 2 and $5 \mathrm{~Hz}$. Because the base frequency was 0.1 $\mathrm{Hz}$, the waveform was repeated every $1 \mathrm{~s}$, which was required for good resolution of the current response. 
The largest peaks were utilized to calculate the corrosion current density ( $\left.i_{\text {corr }}\right)$, Tafel lines (c and a), and fitting together factors $\mathrm{CF}-2$ and $\mathrm{CF}-3^{25}$.

All electrochemical tests were carried out using a Gamry PCI300/4 Potentiostat/Galvanostat/Zraanalyzer. For data fitting and calculation, a personal computer running DC 105 software for PP, EIS300 program for EIS, EFM140 software for EFM, and Echem Analyst 5.21 was utilized.

Surface examination study. The coin surfaces were examined using a JSM-6390AL model before and after dipping in corrosive conditions for one day. Meanwhile, the components in the material were analyzed using an energy dispersive spectrometer (EDX). The nature of the film generated on the surface of the metal coins was investigated using these techniques. The roughness of the surfaces was checked utilizing atomic force microscopy (AFM) at the Faculty of Engineering, Mansoura University, Egypt.

\section{Results data and discussion}

WL measurements. Figure 1 contains the WL-time plots of LCS in Polluted NaCl solution with existing and nonexistent altered concentrations of MPE. The corrosion rate $\left(\mathrm{mg} \mathrm{cm}^{-2} \mathrm{~min}^{-1}\right)$, degree of surface coverage $(\Theta)$ and $\mathrm{PE} \%$ at $25^{\circ} \mathrm{C}$ are tabulated in Table 1 . Inspection of Table 1 reveals that the corrosion rate of LCS is highly reduced upon the addition of MPE due to the large coverage of the LCS surface by extracted molecules. This result indicates that MPE acts as a good corrosion inhibitor for LCS in this aggressive medium. $(\theta)$ and \%PE are calculated using Eq. $(1)^{26}$

$$
\% P E=\frac{W o-W i}{W o} \times 100=\theta \times 100
$$

where $\mathrm{W}_{\mathrm{o}}$ and $\mathrm{W}_{\mathrm{i}}$ are the mass loss in the absence and presence of extract, respectively. As revealed from the data in Table 1, the extract has quite a high \%PE that reaches $91.2 \%$ for $300 \mathrm{ppm}$ of the extract. By increasing the extract concentration, the percent PE increased. The extract can be adsorbed on the LCS surface due to unpaired electrons present on their oxygen atoms and/or electrostatic attraction, according to the chemical structures of the extract. The extract's adsorption on the metal provides a charge and mass transfer barrier, which reduces the metal's contact with the corrosive environment. As a result, the metal's corrosion rate is lowered.

Table 1. The impact of MPE concentrations on the WL $\left(\mathrm{mg} \mathrm{cm}^{-2}\right)$ and $(\Theta)$ of LCS in 3.5 percent $\mathrm{NaCl}+$ $16 \mathrm{ppm} \mathrm{Na}_{2} \mathrm{~S} 25^{\circ} \mathrm{C}$.

\begin{tabular}{|c|c|c|c|}
\hline \multirow{2}{*}{ Conc. ppm } & \multicolumn{3}{|c|}{$25^{\circ} \mathrm{C}$} \\
\cline { 2 - 4 } & WL, $\mathrm{mg} \mathrm{cm}^{-2}$ & $\Theta$ & $\%$ PE \\
\hline Blank & $0.70710 \pm 0.1721$ & ---- & -- \\
\hline 50 & $0.3333 \pm 0.2303$ & 0.519 & 51.9 \\
\hline 100 & $0.2711 \pm 0.2644$ & 0.617 & 61.7 \\
\hline 150 & $0.2381 \pm 0.2885$ & 0.663 & 66.3 \\
\hline 200 & $0.1557 \pm 0.2028$ & 0.780 & 78.0 \\
\hline 250 & $0.1027 \pm 0.2336$ & 0.855 & 85.5 \\
\hline 300 & $0.0620 \pm 0.2818$ & 0.912 & 91.2 \\
\hline
\end{tabular}




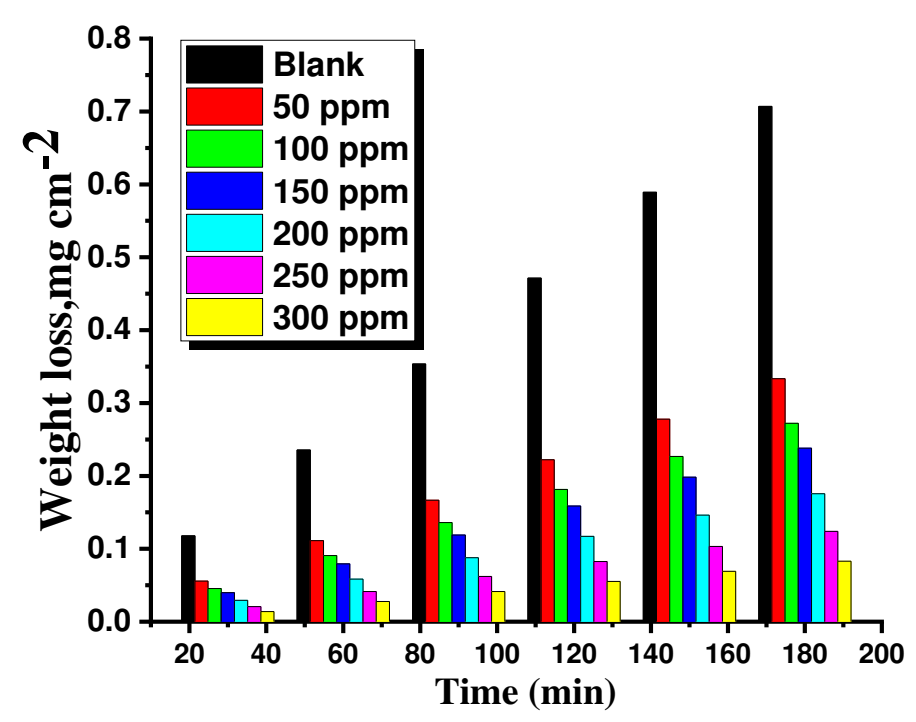

Figure 1. WL- time diagram for the dissolution of LCS in polluted $\mathrm{NaCl}$ with and without altered concentrations of MPE at $25^{\circ} \mathrm{C}$

Impact of temperature. The WL technique was used to investigate the impact of temperature on the corrosion characteristics of LCS in polluted $\mathrm{NaCl}$ solution with and without altered doses of MPE in the temperature range of $25-40^{\circ} \mathrm{C}$. Temperature has a significant impact on the PE of the extract on the LCS, as shown in Table 2 and Fig. 2 A-C, which decreases as temperature rises.

Table 2 shows the effects of MPE concentrations on LCS WL and protection efficiency (percent PE) in 3.5 percent $\mathrm{NaCl}+16 \mathrm{ppm} \mathrm{Na}_{2} \mathrm{~S}$ (polluted $\mathrm{NaCl}$ ) at various temperatures.

\begin{tabular}{|c|c|c|c|c|c|c|}
\hline \multirow{2}{*}{$\begin{array}{c}\text { Conc. } \\
\text { ppm }\end{array}$} & \multicolumn{2}{|c|}{$30^{\circ} \mathrm{C}$} & \multicolumn{2}{c|}{$35^{\circ} \mathrm{C}$} & \multicolumn{2}{c|}{$40^{\circ} \mathrm{C}$} \\
\cline { 2 - 7 } & $\begin{array}{c}\mathrm{WL} \\
\mathrm{mg} \mathrm{cm}^{-2}\end{array}$ & $\begin{array}{c}\% \\
\mathrm{PE}\end{array}$ & $\begin{array}{c}\mathrm{WL} \\
\mathrm{mg} \mathrm{cm}^{-2}\end{array}$ & $\% \mathrm{PE}$ & $\begin{array}{c}\mathrm{WL}, \\
\mathrm{mg} \mathrm{cm}^{-2}\end{array}$ & $\% \mathrm{PE}$ \\
\hline Blank & $0.73230 \pm 0.2309$ & --- & $0.7702 \pm 0.3302$ & --- & $0.83333 \pm 0.2635$ & --- \\
\hline 50 & $0.3629 \pm 0.2027$ & 50.4 & $0.4062 \pm 0.2309$ & 47.3 & $0.4642 \pm 0.2025$ & 44.3 \\
\hline 100 & $0.2990 \pm 0.2333$ & 59.2 & $0.3397 \pm 0.1732$ & 5598 & $0.3977 \pm 0.1734$ & 52.3 \\
\hline 150 & $0.2598 \pm 0.1763$ & 64.5 & $0.3101 \pm .2309$ & 59.7 & $0.3679 \pm 0.2811$ & 55.9 \\
\hline 200 & $0.1866 \pm 0.1452$ & 74.5 & $0.2279 \pm 0.0176$ & 70.4 & $0.3009 \pm 0.2810$ & 63.9 \\
\hline 250 & $0.1239 \pm 0.2886$ & 83.1 & $0.1650 \pm 0.0176$ & 78.6 & $0.2169 \pm 0.2882$ & 74.0 \\
\hline 300 & $0.0889 \pm 0.2027$ & 87.9 & $0.1086 \pm 0.2335$ & 85.9 & $0.1778 \pm 0.1724$ & 78.7 \\
\hline
\end{tabular}

Arrhenius processes are commonly used to describe corrosion reactions, and the rate $\left(\mathrm{k}_{\text {corr }}\right)$ can be stated using the equation in Eq. (2):

$$
\text { “k } k_{\text {corr }}=A e^{\left(-E^{*} a / R T\right) "}
$$

where $k_{\text {corr }}$ is the corrosion rate, $E_{a}^{*}$ is the apparent activation energy, $R$ is the universal gas constant, $T$ is the absolute temperature, and $A$ is the frequency factor. Fig. 3 shows an Arrhenius plot (log $\mathrm{k}_{\text {corr }}$ against the reciprocal of temperature $(1 / \mathrm{T}))$ followed by straight lines with high correlation coefficients. For the blank and extract, the activation energy $\mathrm{E}_{\mathrm{a}}{ }^{*}$ ranged from 8.5 to 42.7 (Table 3). Physical adsorption or weak chemical interaction between the extract molecules and the LCS surface is indicated by a rise in $\mathrm{E}_{\mathrm{a}}{ }^{*}$ when the extract is present ${ }^{27}$. Eq. (3) is used to compute the activation enthalpy and entropy $\left(\Delta \mathrm{H}^{*}, \Delta \mathrm{S}^{*}\right)$ utilizing transition state theory: 


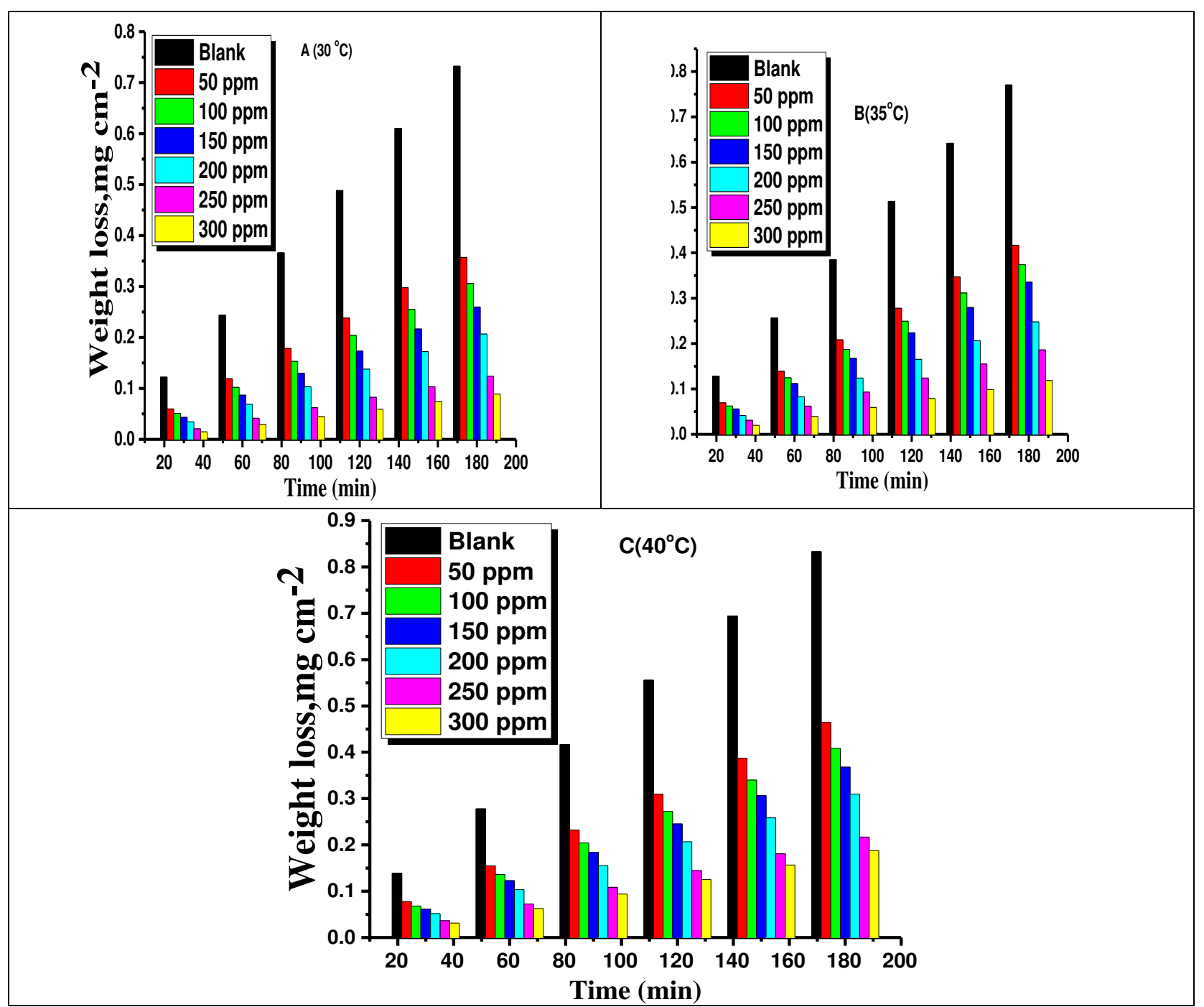

Figure 2(A-C). WL-time diagrams for the corrosion of $\mathrm{LCS} \mathrm{NaCl} / \mathrm{H}_{2} \mathrm{~S}$ with and without MPE at altered temperatures

"The Arrhenius equation can also be written as":

$$
k_{\text {corr }}=R T / N h \exp \left(\Delta S^{*} / R\right) \exp \left(-\Delta H^{*} / R T\right)
$$

where $\mathrm{h}$ is Planck's constant and $\mathrm{N}$ is Avogadro's number. A plot of $\log \mathrm{k}_{\text {corr }} / \mathrm{T}$ as a function of $1 / \mathrm{T}$ for LCS is shown in Fig. 4. Straight lines with a slope of $\Delta H^{*} / R$ and an intercept of $\ln R / N h+\Delta S^{*} / R$ were drawn, from which the values of $\Delta \mathrm{H}^{*}$ and $\Delta \mathrm{S}^{*}$ for the blank and extract were computed". "The activation enthalpy, $\Delta \mathrm{H}^{*}$, was 6.0 and $40.8 \mathrm{~kJ} \mathrm{~mol}^{-1}$ for the blank and the extract, respectively, while the activation entropy, $\Delta \mathrm{S}^{*}$, was 177.9 and $271.0 \mathrm{~J} \mathrm{~mol}^{-1} \mathrm{~K}^{-1}$ for the extract (Table 3). In the absence and presence of extract, the $\Delta \mathrm{S}^{*}$ is substantial and negative. This implies that the activated complex in the rate determining step represents an association rather than a dissociation step, meaning that a decrease in disordering takes place on going from reactants to the activated complex ${ }^{28,29}$. The positive sign of $\Delta \mathrm{H}^{*}$ indicates that the corrosion process is endothermic. 


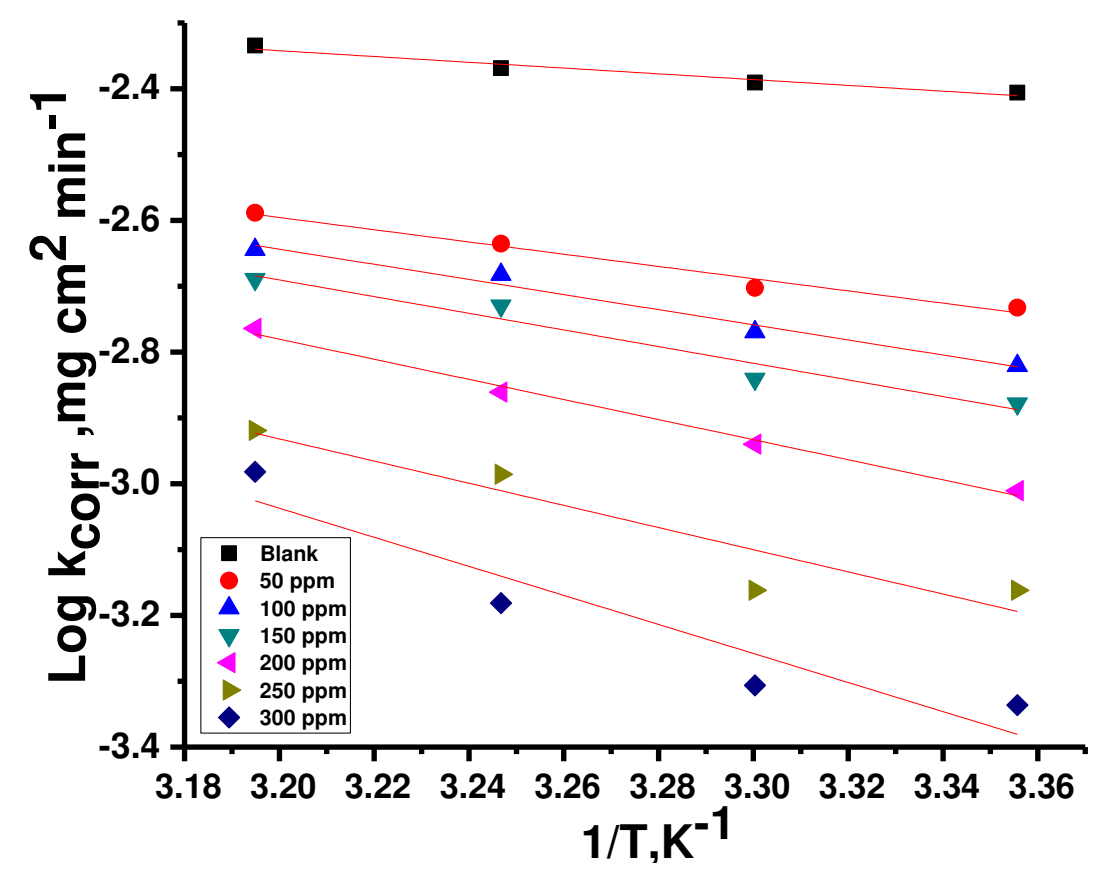

Figure 3. Arrhenius plots for the corrosion rate of LCS in $\mathrm{NaCl} / \mathrm{H}_{2} \mathrm{~S}$ in the absence and presence of MPE at different temperatures.

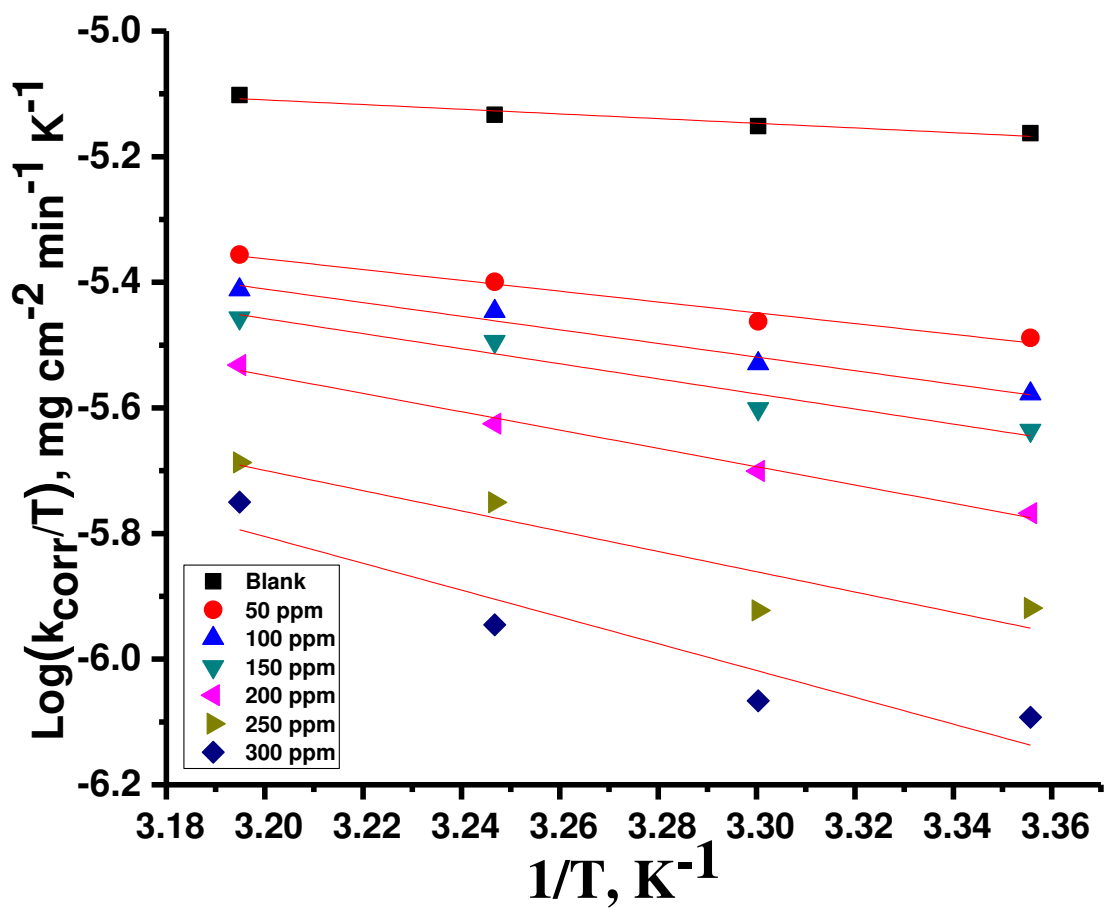

Figure 4. $\log \left(\mathrm{k}_{\text {corr }} / \mathrm{T}\right)$ versus $1 / \mathrm{T}$ for LCS in sulfide-polluted saltwater in the absence and presence of MPE at different temperatures

Table 3. Activation parameters for LCS corrosion in the absence and presence of various concentrations of investigated MPE

\begin{tabular}{|l|c|c|c|}
\hline Conc., $\mathrm{ppm}$ & $\mathrm{E}_{\mathrm{a}}^{*}, \mathrm{~kJ} \mathrm{~mol}^{-1}$ & $\Delta \mathrm{H}^{*}, \mathrm{~kJ} \mathrm{~mol}^{-1}$ & $-\Delta \mathrm{S}^{*}, \mathrm{~J} \mathrm{~mol} \mathrm{~K}$ \\
\hline
\end{tabular}




\begin{tabular}{|c|c|c|c|}
\hline Blank & $8.5 \pm 0.2731$ & $6.0 \pm 01452$ & $271.0 \pm 0.233$ \\
\hline 50 & $18.0 \pm 0.3734$ & $16.4 \pm 01732$ & $247.5 \pm 0.234$ \\
\hline 100 & $22.2 \pm 0.1742$ & $20.7 \pm 02024$ & $234.7 \pm 0.145$ \\
\hline 150 & $24.5 \pm 0.2333$ & $23.0 \pm 02021$ & $228.5 \pm 0.2027$ \\
\hline 200 & $29.5 \pm 0.2603$ & $28.0 \pm 02022$ & $214.4 \pm 0.3179$ \\
\hline 250 & $32.6 \pm 02309$ & $30.8 \pm 01732$ & $207.7 \pm 0.3179$ \\
\hline 300 & $42.7 \pm 01201$ & $40.8 \pm 02027$ & $177.9 \pm 0.3179$ \\
\hline
\end{tabular}

Adsorption isotherms. To study the adsorption behavior of MPE on the LCS surface in the given medium, the adsorption isotherm must be defined to explain the mechanism of the extract reaction. The best fit isotherm is Timken adsorption isotherm. On its active sites, the extract is adsorbed on the metal surface. $\theta$ values for altered extract doses at various temperatures were tested by fitting to various isotherms. Therefore, the relation between the dose of the extract $(\mathrm{C}),(\theta)$ and the adsorption equilibrium constant $\left(K_{a d s}\right)$ was obtained from the Timken adsorption isotherm:

$$
\mathrm{a} \Theta=\ln K_{a d s} \mathrm{C}
$$

where (a) is the heterogeneity factor, $\mathrm{C}$ is the concentration of extract and $K_{a d s}$ is the constant of adsorption equilibrium, "which is related to the standard free energy of adsorption $\left(\Delta \mathrm{G}_{\text {ads }}^{\mathrm{o}}\right)$ by the equation":

$$
\text { "K } K_{a d s}=(1 / 55.5) \exp \left(\Delta \mathrm{G}_{\text {ads }}^{\mathrm{o}} / \mathrm{RT}\right) "
$$

where 55.5 is the concentration of water in $\mathrm{mol} / \mathrm{L}$ at the metal solution interface. The plot of $(\Theta)$ as a function of logarithm of the extract dose is shown in Fig. 5. From the plot, straight lines were obtained for the extract, indicating that the experimental data fit well into the Temkin adsorption isotherm. The Temkin isotherm characterizes the chemisorption of uncharged molecules on heterogeneous surfaces. The regression coefficients $\left(\mathrm{R}^{2}\right)$ are about 0.99 . The departure of the slopes from unity is due to molecular interaction between the adsorbed extract species, which is not considered during the deviation: $\Delta \mathrm{G}^{\circ}{ }_{\text {ads }}$ is consistent across all sites and is unaffected by the degree of surface coverage. 4th Table the adsorbate does not interact with one another, i.e., the adsorbate on $\mathrm{G}^{\circ}$ ads has no effective interaction". Table 4 shows that as the temperature rises, the $K_{\text {ads }}$ value drops, indicating that the extract adsorption on the metal surface is reduced. In general, $\mathrm{K}_{\mathrm{ads}}$ refers to the strength of the bond between the adsorbent and the adsorbate. The $\Delta G_{\text {ads }}^{o}$ values were derived from this plot and were negative, indicating that the extract molecules were stable and spontaneously adsorbed on the LCS surface. The heat of adsorption $\left(\Delta \mathrm{H}^{\mathrm{o}}\right.$ ads $)$ can be determined using Vant Hoff's formula:

$$
\text { "Log } K_{a d s}=\left(-\Delta \mathrm{H}^{\mathrm{o}}{ }_{\text {ads }} / 2.303 \mathrm{RT}\right)+\text { constant" }
$$

To calculate the heat of adsorption $\left(\Delta \mathrm{H}^{\circ}{ }_{\text {ads }}\right), \log \mathrm{K}_{\text {ads }}$ was plotted against 1000/T (Fig. 6). A straight line was obtained. The absolute values of $\Delta \mathrm{H}^{\circ}{ }_{\text {ads }}$ obtained in this study were lower than $100 \mathrm{~kJ} \mathrm{~mol}^{-1}$, which is indicative of physisorption and supports the above mechanism of adsorption. The negative value of $\Delta \mathrm{H}^{\mathrm{o}}$ ads $\left(-32.520 \mathrm{~kJ} \mathrm{~mol}^{-1}\right)$ in the presence of the extract reflects the exothermic nature of the LCS dissolution process. The activation enthalpies vary in the same manner as the activation energies, supporting the proposed protection mechanism. According to the basic Eq.:

$$
\text { “ } \Delta \mathrm{G}_{\text {ads }}^{\mathrm{o}}=\Delta \mathrm{H}_{\text {ads }}^{\mathrm{o}}-\mathrm{T} \Delta \mathrm{S}_{\text {ads }}^{\mathrm{o}} \text { “ }
$$

The adsorption entropy, $\Delta \mathrm{S}^{\mathrm{o}}$ ads, was determined. The large negative entropy values in the presence of this investigated extract indicates that the activated complex in the rate-determining step represents an association rather than a dissociation step, implying that disordering decreases as one moves from 
reactants to the activated complex, and the activated molecules are in a higher order state than at the start 30,31 .

Table 4. Adsorption parameters for LCS in the absence and presence of various concentrations of MPE

\begin{tabular}{|c|c|c|c|c|}
\hline $\begin{array}{c}\text { Temp. } \\
\mathrm{K}\end{array}$ & $\begin{array}{c}-\mathrm{Log} \\
\mathrm{K}_{\mathrm{ads}}\end{array}$ & $\begin{array}{c}-\Delta \mathrm{G}_{\mathrm{ads}}^{\mathrm{o}} \\
\mathrm{kJ} \mathrm{mol}^{-1}\end{array}$ & $\begin{array}{c}-\Delta \mathrm{H}^{\mathrm{o}} \\
\mathrm{kJ} \mathrm{mol}^{-1}\end{array}$ & $\begin{array}{c}-\Delta \mathrm{S}^{\mathrm{O}} \\
\mathrm{J} \mathrm{mol}^{-1} \mathrm{~K}^{-1}\end{array}$ \\
\hline 298 & 2.4088 & $23.9 \pm 0.2332$ & & $189.5 \pm 0.3756$ \\
\hline 303 & 2.2970 & $23.7 \pm 0.5532$ & \multirow{3}{*}{32.5} & $185.6 \pm 0.4435$ \\
\hline 308 & 2.1331 & $23.1 \pm 0.2265$ & & $180.7 \pm 0.4967$ \\
\cline { 1 - 3 } \cline { 5 - 5 } & & & $181.1 \pm 0.3232$ \\
\hline 313 & 2.2425 & $24.2 \pm 0.4123$ & &
\end{tabular}

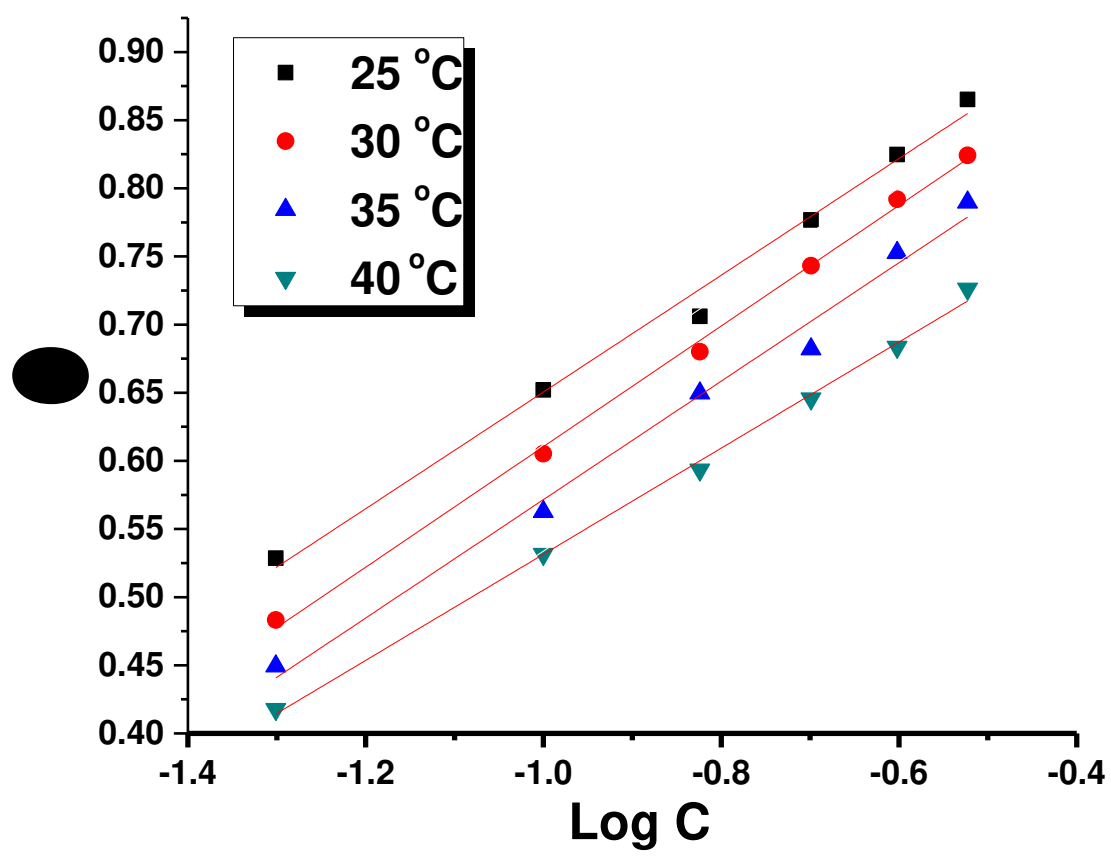

Figure 5. Temkin adsorption isotherm for MPE at different temperatures for the LCS in $\mathrm{NaCl} / \mathrm{H}_{2} \mathrm{~S}$ solution

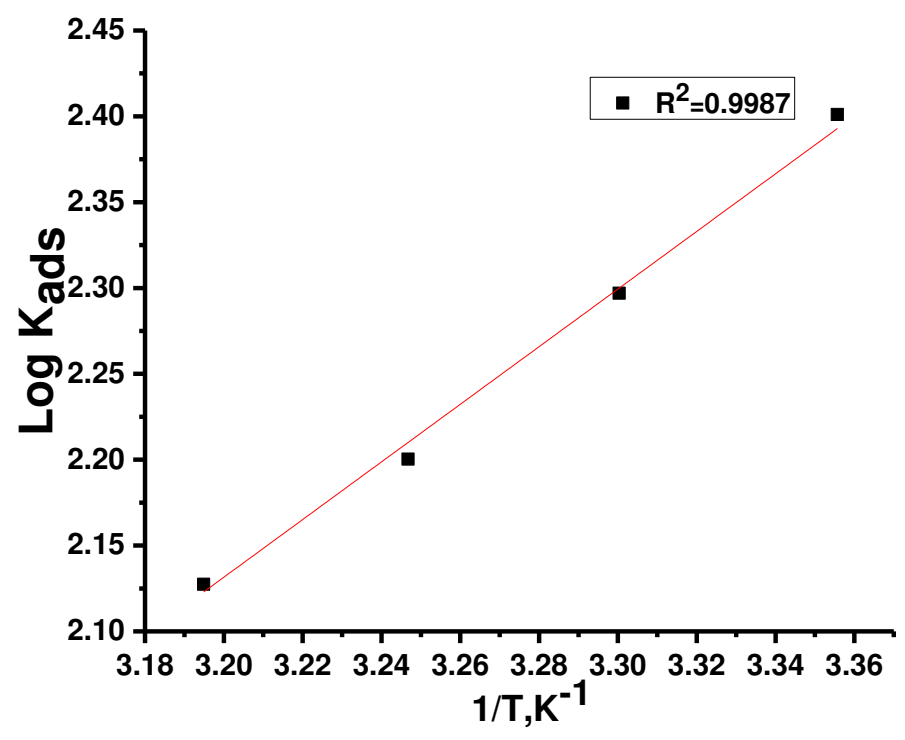


Figure 6. $\log \mathrm{K}_{\mathrm{ads}}$ vs 1000/T for the dissolution of the LCS in presence of MPE

PP measurements. The most common corrosion events are electrochemical in nature and consist of reactions on the surface of the corroding metal. Previously, electrochemical approaches could be used to assess corrosion rates and describe corrosion processes. The inclusion of the extract during the polarization process is a criterion for classifying the kind of extract action, such as anodic, cathodic, or mixed. At $25^{\circ} \mathrm{C}$, the Tafel polarization curve of LCS in polluted $\mathrm{NaCl}$ in existing and absence altered doses of MPE is shown in Fig. 7. The anodic and cathodic current densities of LCS in the presence of MPE were substantially lower than those of the blank. This decline becomes more pronounced as the MPE dose rises. Furthermore, when MPE is added to a $1 \mathrm{M} \mathrm{HCl}$ solution, a slight shift in the corrosion potential toward greater positive potentials is seen. The cathodic component shows the emergence of parallel Tafel lines, showing that activation controls hydrogen development. As a result, hydrogen discharge is predominantly accomplished at the LCS surface via a charge transfer mechanism [32]. As a result, the inhibition process might be induced by a simple blocking surface effect, such as a decrease in reaction area on the corroding surface $0^{33,34}$. At each concentration, the values of $\mathrm{PE}$ and $\Theta$ were determined using Eq. $8^{35,36}$.

$$
\text { “\% } \mathrm{PE}=\theta \times 100=\left(1-\mathrm{i}_{\text {corr }} / \mathrm{i}_{\mathrm{corr}(\mathrm{inh}}\right) \times 100 "
$$

where $i_{\text {corr }}$ and $i_{\text {corr(inh) }}$ are the corrosion current densities of uninhibited and inhibited solutions, respectively. Table 5 shows that when the extract concentration increases, the $i_{\text {corr }}$ values drop. The increase in extract concentration causes a considerable shift in $\beta_{\mathrm{a}} \& \beta_{\mathrm{c}}$, indicating a mixed type of inhibitor $^{37}$. The protective efficacy of the extract improved as the concentration of the extract increased. MPE is a mixed-type inhibitor with cathodic action as its main feature. Following the addition of the extract, the polarization curves altered toward a lower negative potential and lower current density values, as shown in Fig. 7, indicating that MPE's protection mode is simple surface blockage by adsorption. The extract species are adsorbed on the metal surface by the donor atoms of oxygen and the electron clouds of the benzene rings, increasing the $(\theta)$ as the extract concentration increased. The bulky group of the extract also prevents ions from diffusing to or from the electrode surface ${ }^{38}$. As a result, the anodic dissolution current density of LCS is reduced.

Table 5.The impact of the concentration of MPE on the electrochemical parameters calculated by using the PP technique for dissolution of LCS in $\mathrm{NaCl} / \mathrm{Na}_{2} \mathrm{~S}$ at $25^{\circ} \mathrm{C}$

\begin{tabular}{|c|c|c|c|c|c|c|c|}
\hline $\begin{array}{c}\text { Conc. } \\
\text { ppm }\end{array}$ & $\begin{array}{c}-\mathrm{E}_{\text {corr }}, \\
\mathrm{mV} \text { vs SCE }\end{array}$ & $\begin{array}{c}\mathrm{i}_{\text {corr }}, \\
\mu \mathrm{A} \mathrm{cm}^{-2}\end{array}$ & $\begin{array}{c}-\beta_{\mathrm{c}}, \\
\mathrm{mV} \mathrm{dec}^{-1}\end{array}$ & $\begin{array}{c}\beta_{\mathrm{a}}, \\
\mathrm{mV} \mathrm{dec}^{-1}\end{array}$ & $\begin{array}{c}\text { C.R } \\
\mathrm{mmy}^{-1}\end{array}$ & $\theta$ & $\% \mathrm{PE}$ \\
\hline Blank & $1040 \pm 0.4711$ & $264 \pm 0.3154$ & $242 \pm 0.3165$ & $340 \pm 0.4511$ & 120 & ------ & ----- \\
\hline 50 & $733 \pm 0.4934$ & $120 \pm 0.4776$ & $11280 \pm 0.4354$ & $381 \pm 0.5054$ & 58.18 & 0.545 & 54.5 \\
\hline 100 & $812 \pm 0.5561$ & $100 \pm 0.4541$ & $270 \pm 0.4722$ & $350 \pm 0.2733$ & 49.54 & 0.621 & 62.1 \\
\hline 150 & $733 \pm 0.4341$ & $90 \pm 0.2554$ & $281 \pm 0.2622$ & $325 \pm 0.3244$ & 42.27 & 0.659 & 65.9 \\
\hline 200 & $665 \pm 0.2898$ & $61 \pm 0.5132$ & $294 \pm 0.3376$ & $330 \pm 0.5176$ & 30.45 & 0.769 & 76.9 \\
\hline 250 & $664 \pm 0.4022$ & $35 \pm 0.6223$ & $245 \pm 0.2534$ & $372 \pm 0.4376$ & 17.72 & 0.867 & 86.7 \\
\hline 300 & $665 \pm 0.4911$ & $30 \pm 0.3087$ & $239 \pm 0.3687$ & $360 \pm 0.3121$ & 15.0 & 0.886 & 88.6 \\
\hline
\end{tabular}




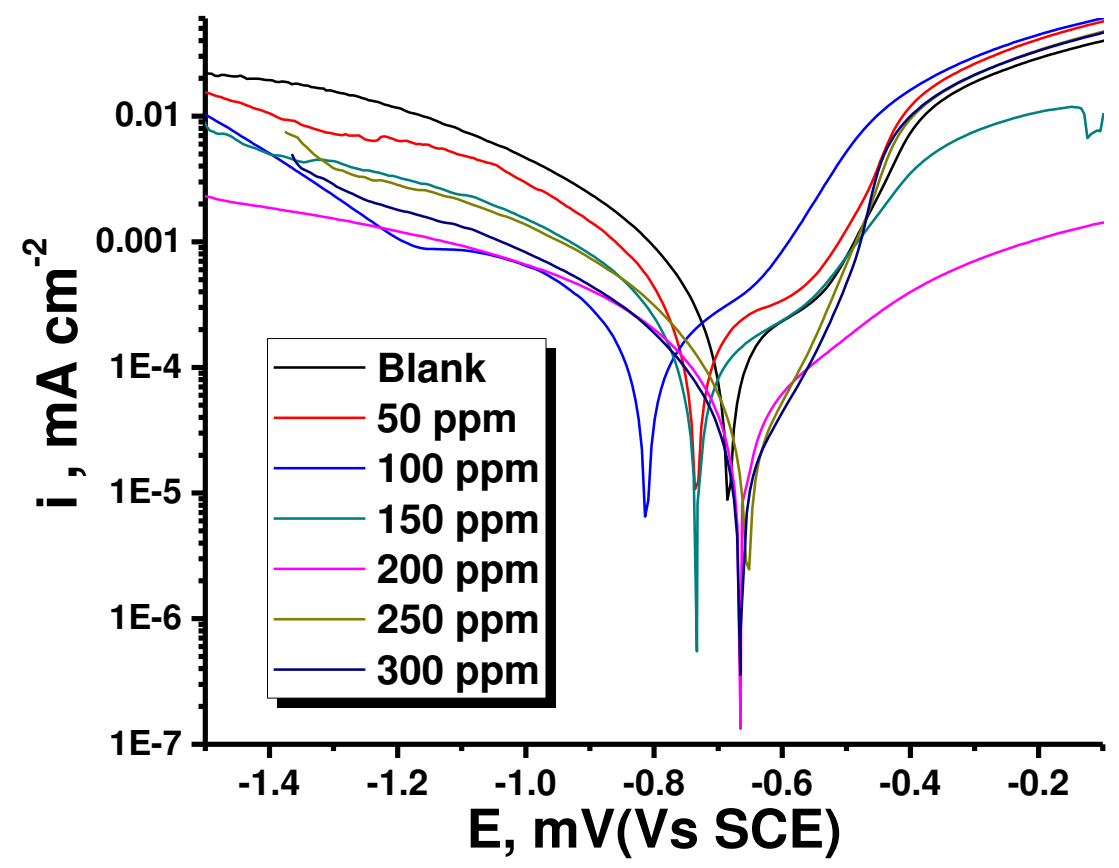

Figure 7. PP curves for the corrosion of $\mathrm{LCS}$ in $\mathrm{NaCl} / \mathrm{Na}_{2} \mathrm{~S}$ with and without altered concentrations of MPE at $25^{\circ} \mathrm{C}$

EIS measurements. Impedance measurements are frequently used to gain a better understanding of the process at LCS contact. EIS was carried out in a blank and inhibited solution containing varying concentrations of MPE under potentiostatic conditions at $25^{\circ} \mathrm{C}$. Impedance tests reveal how the extract can be produced into a thin layer film on the metal surface. Figure 8 shows the corrosion behavior of LCS with and without MPE in 3.5 percent $\mathrm{NaCl}$ and $16 \mathrm{ppm} \mathrm{Na}_{2} \mathrm{~S}$. As indicated by Tsuru et al. [39], the charge-transfer resistance $\left(R_{c t}\right)$ values are determined from the difference in impedance at lower and higher frequencies. The following equation yields the double-layer capacitance $\left(\mathrm{C}_{\mathrm{dl}}\right)$ and the frequency at which the imaginary component of the impedance is maximal (-Zmax):

$$
C_{d l}=\frac{1}{2 \pi \mathrm{f}_{\max } \mathrm{R}_{\mathrm{t}}}
$$

where $f_{\max }$ is the maximum frequency at which the imaginary component of the impedance $\left(Z_{i m}\right)$ is at its maximum at $\mathrm{R}_{\mathrm{t}}$ is the diameter of the loop". The $\mathrm{PE}_{\mathrm{ct}}$ obtained from the charge transfer resistance is calculated by:

$$
\mathrm{PE}_{\mathrm{ct}} \%=100 \times\left(1-\mathrm{R}_{\mathrm{t}} / \mathrm{R}_{\mathrm{t} / \mathrm{inh}}\right)
$$

$\mathrm{R}_{\mathrm{t}}$ and $\mathrm{R}_{\mathrm{t} / \mathrm{inh}}$ are the charge-transfer resistance values without and with extract, respectively. The semicircle indicates that the corrosion process was primarily controlled by charge transfer [40]. "The general form of the curves is extremely similar for all samples, showing that the addition of the extract had essentially little effect on the corrosion mechanism ${ }^{41}$ ". The diameter of the Nyquist plots grew as the extract concentration rose. These findings suggested that increasing extract concentrations improves PE. Table 6 shows that raising the extract concentration improve the charge transfer resistance $\left(\mathrm{R}_{\mathrm{ct}}\right)$ while decreasing the double layer capacitance $\left(\mathrm{C}_{\mathrm{dl}}\right)$. The steady replacement of water molecules by extract molecules adsorbing on the metal surface to produce an adherent layer on the metal surface could explain the increase in $R_{c t}$ values and, as a result, protection efficiency. Because of roughness and potential oxide surface imperfections, the $\mathrm{n}$ value appears to be connected to the no uniform distribution of current. CPE indicates a perfect capacitor when $n=1$. Because genuine capacitive behavior is rare, CPE is commonly employed for data fitting instead of a perfect capacitor. The current investigation demonstrates that $\mathrm{n}<1$ in both uninhibited and inhibited media, demonstrating surface heterogeneity despite MPE adsorption on 
the LCS surface's most active adsorption sites. According to the literature, the modest drop in $\mathrm{n}$ is a sign of surface inhomogeneity caused by inhibitor adsorption ${ }^{42}$. In our situation, the reverse tendency is seen, indicating an increase in homogeneity when MPEO is adsorbed. The results show that the corrosion efficiency values obtained using the impedance approach and polarization measurements are in good agreement. The corrosion rate is determined by the chemical composition of the electrolyte rather than the technology used ${ }^{43}$. The EIS data were reproduced using equivalent electric circuits, as illustrated in Fig. 9, with $\mathrm{R}_{\mathrm{S}}$ denoting solution or electrolyte resistance, $\mathrm{C}_{\mathrm{dl}}$ denoting double layer capacitance, and $\mathrm{R}_{\mathrm{ct}}$ denoting charge transfer resistance. The chi square value $(\chi 2)^{44}$ is used to assess the quality of fitting to the analogous circuit. Table 6 shows the appropriate values $(0.0281-0.0951)$, which demonstrate the high-quality fitting with the suggested circuit.

Table 6. "Electrochemical kinetic parameters obtained by EIS technique for the corrosion of LCS using MPE as extract in $\mathrm{NaCl} / \mathrm{Na}_{2} \mathrm{~S}$ at $25^{\circ} \mathrm{C}$ "

\begin{tabular}{|c|c|c|c|c|c|c|}
\hline $\begin{array}{c}\text { Conc., } \\
\text { ppm }\end{array}$ & $\begin{array}{c}\mathrm{R}_{\mathrm{s},} \\
\Omega \mathrm{cm}^{2}\end{array}$ & $\begin{array}{c}C_{d l,} \\
\mu \mathrm{Fcm}^{-2}\end{array}$ & $\mathrm{n}$ & $\begin{array}{c}\mathrm{R}_{\mathrm{ct},} \\
\Omega \mathrm{cm}^{2}\end{array}$ & $\theta$ & $\% \mathrm{PE}$ \\
\hline Blank & $5.561 \pm 0.5111$ & $163.74 \pm 0.4343$ & 0.867 & 31.72 & ---- & ---- \\
\hline 50 & $4.171 \pm 0.5554$ & $86.70 \pm 0.2976$ & 0.883 & 65.34 & 0.477 & 47.7 \\
\hline 100 & $4.155 \pm 0.3776$ & $71.62 \pm 0.5232$ & 0.842 & 84.83 & 0.575 & 57.5 \\
\hline 150 & $4.845 \pm 0.4676$ & $64.83 \pm 0.4911$ & 0.897 & 88.63 & 0.622 & 62.2 \\
\hline 200 & $3.359 \pm 0.3798$ & $48.56 \pm 0.4145$ & 0.878 & 115.46 & 0.716 & 71.6 \\
\hline 250 & $4.942 \pm 0.3823$ & $32.03 \pm 0.5567$ & 0.888 & 130.42 & 0.823 & 82.3 \\
\hline 300 & $3.642 \pm 0.2221$ & $25.16 \pm 0.3232$ & 0.878 & 143.22 & 0.859 & 85.9 \\
\hline
\end{tabular}

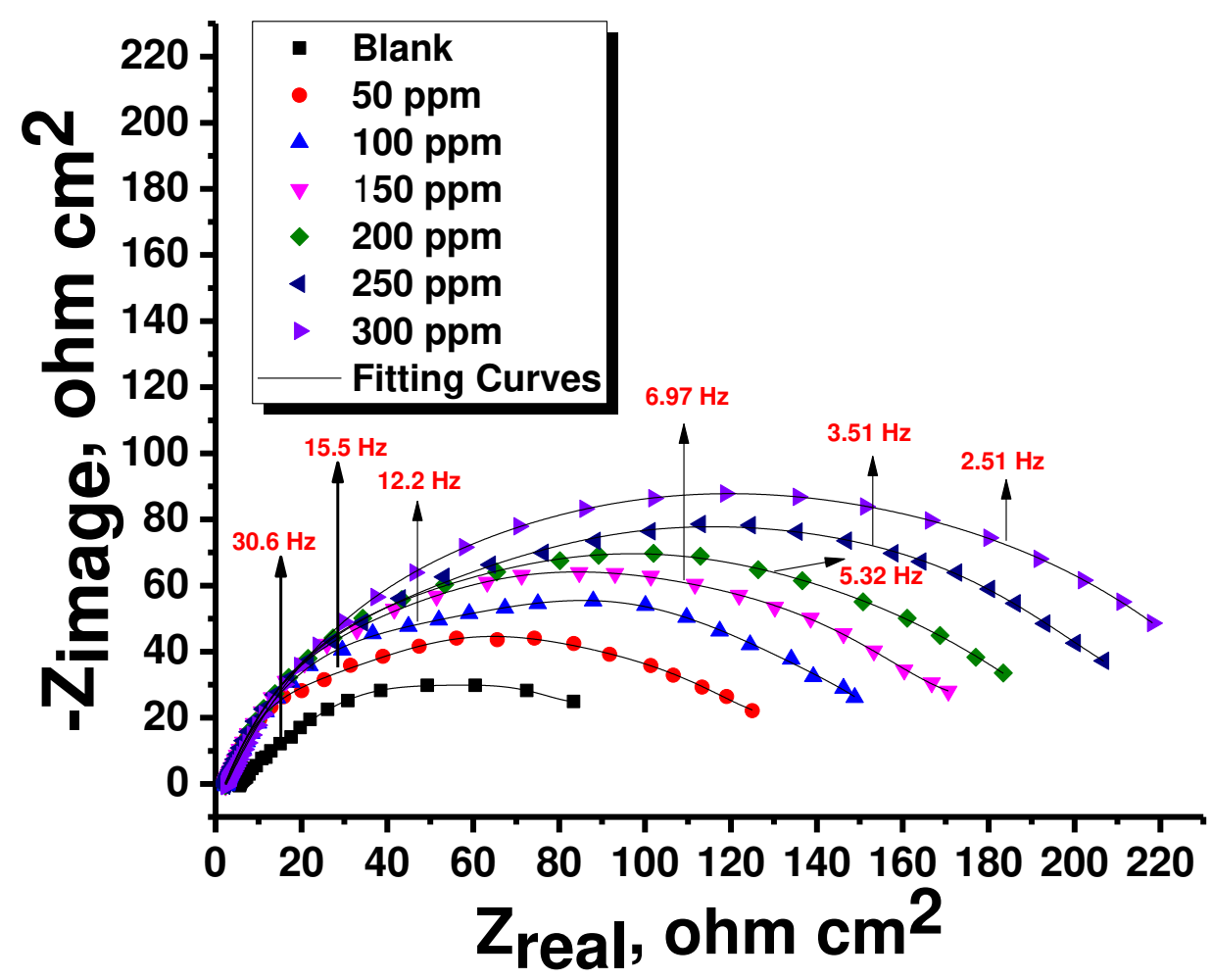

Figure 8. "Nyquist plots recorded for the $\mathrm{LCS}$ in $\mathrm{NaCl} / \mathrm{Na}_{2} \mathrm{~S}$ with and without altered concentrations of MPE at $25^{\circ} \mathrm{C}$ " 


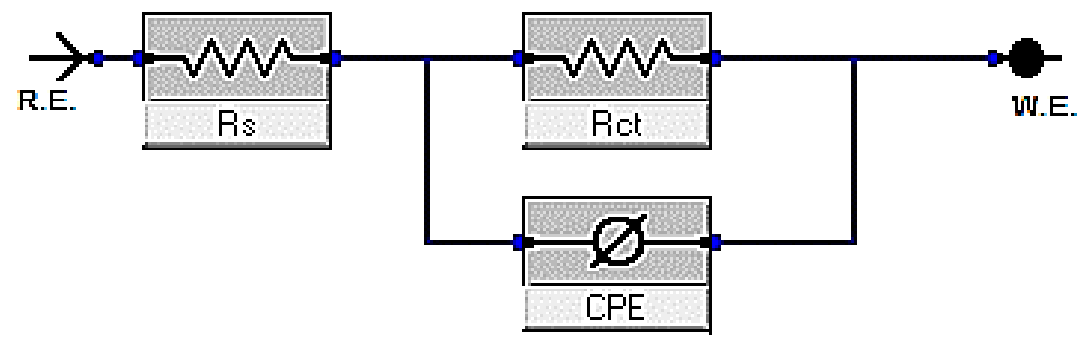

Figure 9. "Electrical equivalent circuit used to fit impedance data"

EFM measurements. With the EFM technique, a potential perturbation by two sine waves of different frequencies is applied to a corroding system. As a corrosion process is nonlinear in nature, responses are generated at more frequencies than the frequencies of the applied signal. The AC current response due to this perturbation consists of current components (peaks) of different frequencies. Analysis of these current responses can result in the corrosion rate and Tafel parameters ${ }^{45}$. Fig. 10 shows intermodulation spectra derived from EFM measurements as examples of LCS in 3.5 percent $\mathrm{NaCl}$ and $16 \mathrm{ppm} \mathrm{Na}_{2} \mathrm{~S}$ with and without $300 \mathrm{ppm} \mathrm{MPE} \mathrm{at} 25^{\circ} \mathrm{C}$. ( $\mathrm{i}_{\text {corr }}, \beta_{\mathrm{c}}, \beta_{\mathrm{a}}, \mathrm{CF}-2, \mathrm{CF}-3$, and percent IE) are all corrosion kinetic characteristics of MPE with varied doses in polluted $\mathrm{NaCl}$ at $25^{\circ} \mathrm{C}$ in Table 7.As the extract concentration rises, the $i_{\text {corr }}$ falls, and the protection efficiency rises. The causation factors in Table 7 are quite close to the theoretical values, which should ensure the validity of the Tafel slope and corrosion current densities, according to EFM theory. The \%IE obtained from the WL, PP, EIS, and EFM approaches were found to be in consistent with each other.

Table 7. Electrochemical kinetic parameters obtained by the EFM technique for LCS in $3.5 \% \mathrm{NaCl}+16$ ppm $\mathrm{Na}_{2} \mathrm{~S}$ alone and with different concentrations of MPE at $25^{\circ} \mathrm{C}$

\begin{tabular}{|c|l|c|c|c|c|c|c|c|}
\hline $\begin{array}{c}\text { Conc., } \\
\text { ppm }\end{array}$ & $\begin{array}{c}\mathrm{i}_{\text {corr, }} \\
\mu \mathrm{A} \mathrm{cm}^{-2}\end{array}$ & $\begin{array}{c}\beta_{\mathrm{a}}, \\
\mathrm{mV} \mathrm{dec}^{-1}\end{array}$ & $\begin{array}{c}\beta_{\mathrm{c}}, \\
\mathrm{mV} \mathrm{dec}^{-1}\end{array}$ & CF-2 & CF-3 & $\begin{array}{c}\text { C.R, } \\
\mathrm{mmy}^{-1}\end{array}$ & $\Theta$ & $\% \mathrm{IE}$ \\
\hline Blank & $678.2 \pm 0.3721$ & $135 \pm 0.4043$ & $185 \pm 0.3534$ & 1.933 & 2.891 & 309.9 & --- & --- \\
\hline 50 & $334.0 \pm 0.5433$ & $156 \pm 0.3755$ & $201 \pm 0.4911$ & 1.881 & 2.935 & 152.6 & 0.508 & 50.8 \\
\hline 100 & $284.0 \pm 0.4954$ & $148 \pm 0.4013$ & $196 \pm 0.3422$ & 1.980 & 2.999 & 129.8 & 0.581 & 58.1 \\
\hline 150 & $246.4 \pm 0.4332$ & $155 \pm 0.4928$ & $207 \pm 0.2265$ & 1.890 & 2.883 & 112.6 & 0.637 & 63.7 \\
\hline 200 & $184.3 \pm 0.4054$ & $142 \pm 0.4616$ & $211 \pm 0.2076$ & 1.923 & 2.974 & 84.2 & 0.728 & 72.8 \\
\hline 250 & $106.3 \pm 0.4911$ & $151 \pm 0.3714$ & $194 \pm 0.4076$ & 1.875 & 2.999 & 48.5 & 0.843 & 84.3 \\
\hline 300 & $88.6 \pm 0.4311$ & $154 \pm 0.3484$ & $212 \pm 0.3182$ & 1.969 & 2.864 & 40.4 & 0.869 & 86.9 \\
\hline
\end{tabular}

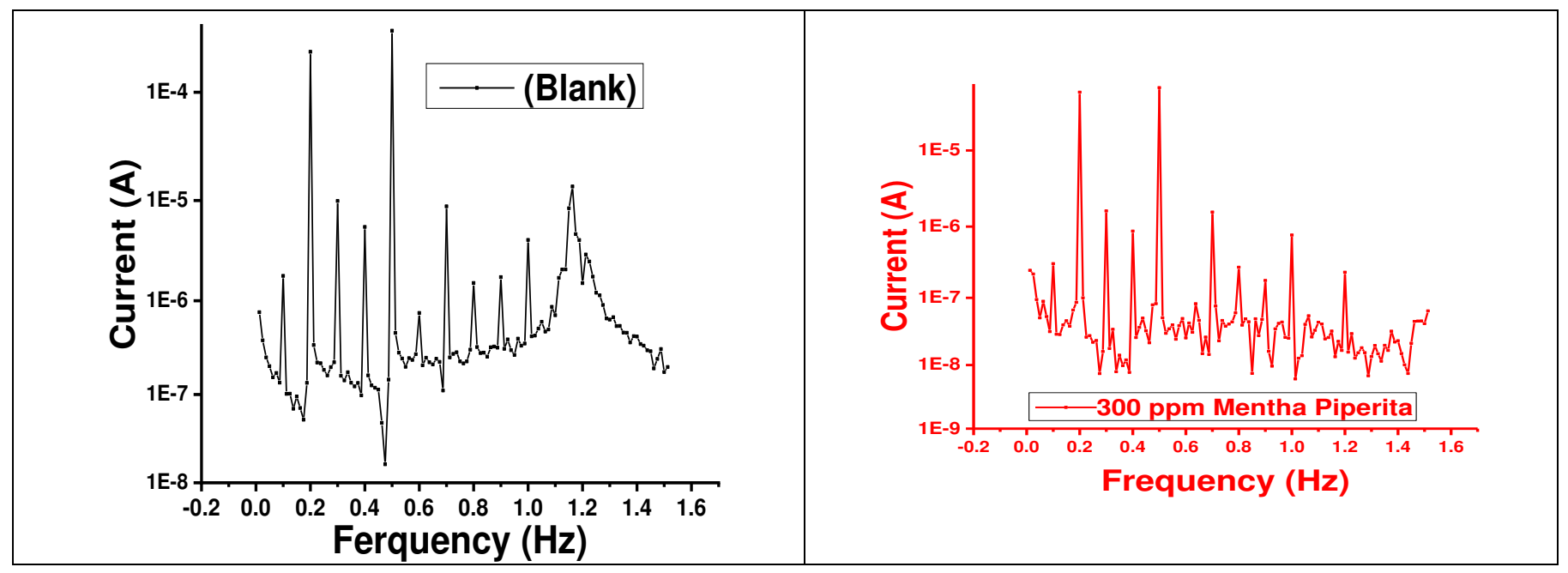


Figure 10. "Intermodulation spectrum for LCS in $3.5 \% \mathrm{NaCl}+16 \mathrm{ppm} \mathrm{Na}_{2} \mathrm{~S}$ solution in the absence and presence of different concentrations of MPE at $25^{\circ} \mathrm{C}$.

Surface characterization. EDX spectra and the corresponding SEM micrographs of the LCS surface only after dipping in the corrosive media with and without the extract for approximately 5 days are shown in Fig. 11(a-c). The image of LCS surface is presented in Fig. 11a. An image of the LCS surface after dipping in corrosive media for approximately 5 days is presented in Fig. 11b, showing distortion due to the porous oxide film layer. The result of adding the extract to the metal surface is shown in Fig 11c, where there is no surface damage, and the surface is smooth. The metal sample is linked to the distinctive peaks. The metal surface has peaks of $\mathrm{Fe}, \mathrm{Mn}, \mathrm{Cl}, \mathrm{Na}$, $\mathrm{S}$, and oxygen atoms after immersion in the corrosive fluids for approximately 5 days, as shown in Fig. $11 \mathrm{~b}$, which is connected to the oxide film generated on the metal surface. Fig. 11c shows the SEM peaks of the effect of the addition of the extract on the metal surface. In Fig. 11c, the peaks of Fe decrease, and the peaks of oxygen increase, which indicates great coverage of the extract on the metal surface, leading to a decrease in the peaks of the Fe atoms, and the extract passivates the metal surface from the corrosive media. Therefore, MPE is a good extract for LCS at a 300-ppm concentration.

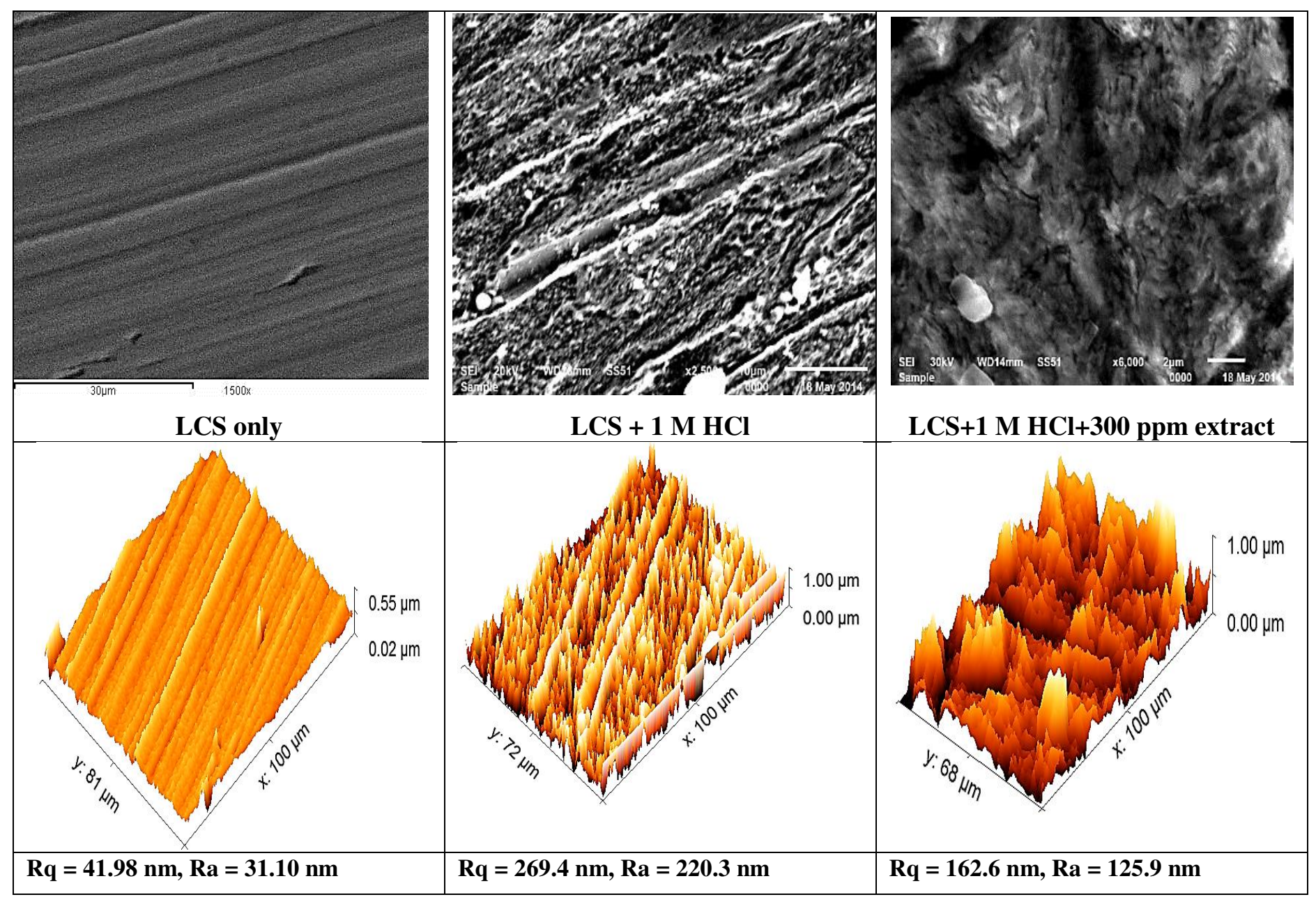




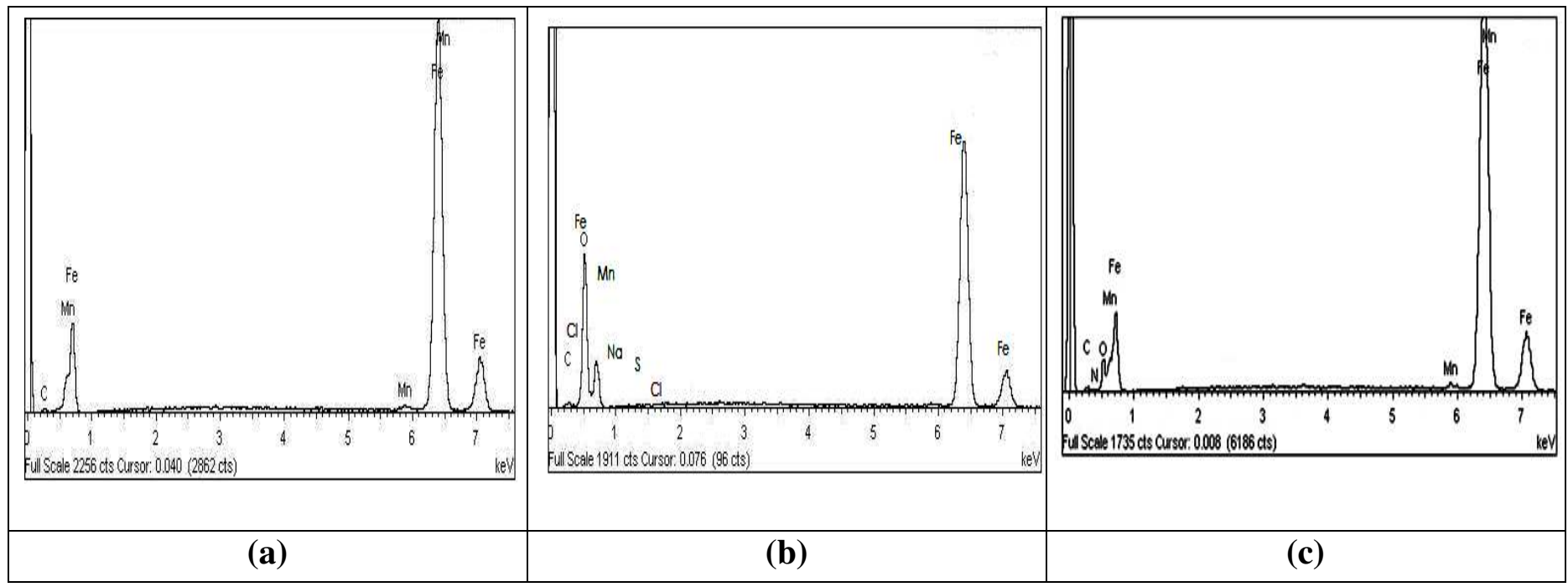

Figure 11. SEM micrographs and EDX spectra of the LCS surface recovered from (a) Pure (b) in corrosive solution and (c) in corrosive solution $+300 \mathrm{ppm}$ extract

Biological effect of MPE on Escherichia Coli. "In the absence and presence of MPE, bacterial agriculture of Escherichia coli is carried out. There was no influence on the activity of Escherichia coli, as shown in Table 8 and Fig. 12. The MPE, which has an oxygen donor atom, is hypothesized to connect to the proteins and lipids of bacterial tissues, assisting in the respiration process. As a result, this extract has no toxicity on bacterial activity and may be safely used in sanitation facilities without causing any problems in the treatment process.

Table 8. Results obtained from the plate counter for bacterial agriculture

\begin{tabular}{|c|c|c|c|}
\hline Samples & CFU (R1) & CFU (R2) & CFU (mean) \\
\hline Control & $89 \times 10^{4}$ & $94 \times 10^{4}$ & $91 \times 10^{4}$ \\
\hline MPE & $89 \times 10^{4}$ & $93 \times 10^{4}$ & $90 \times 10^{4}$ \\
\hline
\end{tabular}
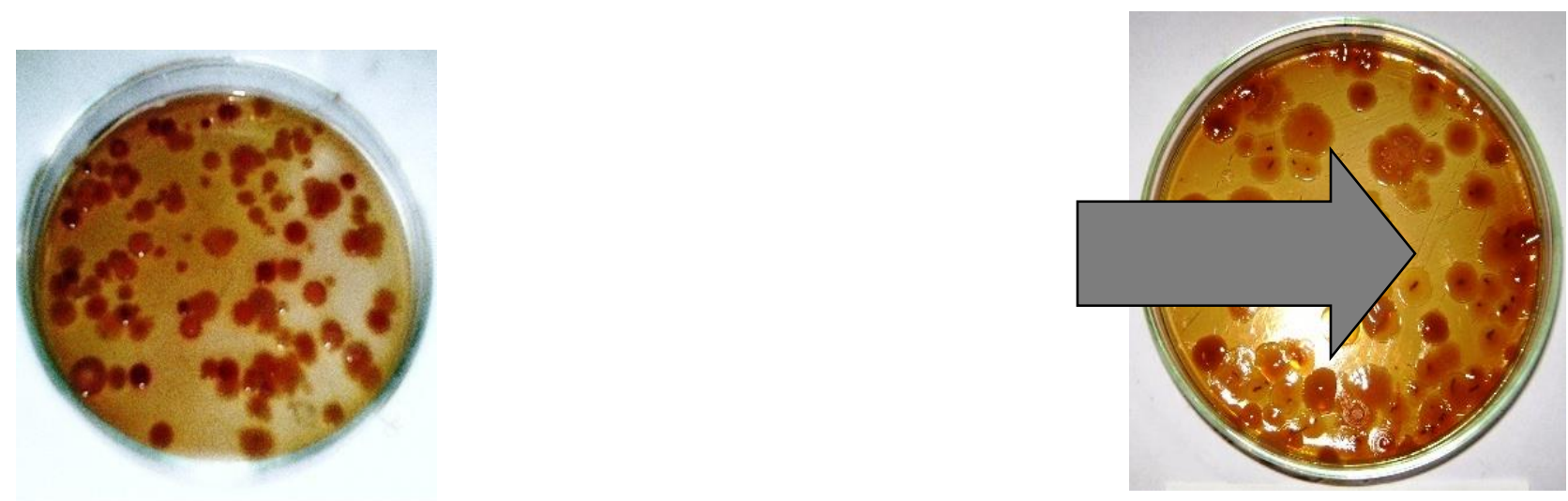

Blank

"The bacterial agriculture in presence of $300 \mathrm{ppm}$ MPE"

Figure 12. Bacterial agriculture in the absence and presence of MPE extract 
Mechanism of corrosion protection. Some MPE molecules can be protonated in the corrosive medium (acquire + ve charge), and the LCS has a positively charged surface, so there is repulsion between it and the protonated molecules. The $\mathrm{Cl}^{-}$ions are adsorbed on the LCS surface and turn its surface negative, after which the protonated molecules are adsorbed on the -ve LCS surface (Figure 13). Diterpenes, steroids, tannins, flavonoids, carbohydrates, alkaloids, phenols, coumarin, and saponins are the primary chemical elements of the phytochemical MPE extract ${ }^{22}$. Most of these phytochemicals are organic molecules with polar functional groups of oxygen $(\mathrm{O})$ and nitrogen $(\mathrm{N})$. A structure such as this promotes the creation of a complex with dissolved iron ions. The production of insoluble complexes is indicated by the result. These complexes are adsorbed onto the LCS by weak pressures, forming a protective layer against the corrosive environment and therefore slowing the dissolving process.

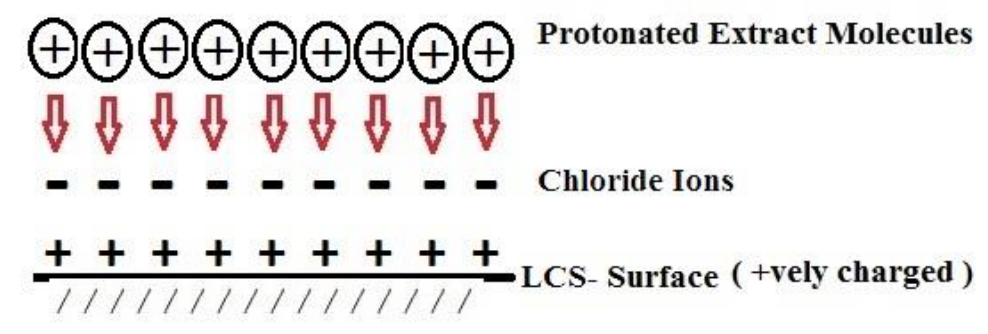

Figure 13. Corrosion inhibition mechanism

\section{Conclusions}

The following data can be drawn based on the obtained data:

In sulfide-polluted saltwater, MPE works as a corrosion extract for LCS, with an efficiency of 87.43 percent at a 300-ppm concentration. MPE adsorption on metal surfaces follows the Timken adsorption isotherm, indicating that it is an effective eco-friendly and low-cost extract. As the temperature rises, the effectiveness of the protection system decreases. Strong and spontaneous adsorption of MPE on the metal surface is indicated by the negative free energy $\left(-\Delta \mathrm{G}_{\mathrm{ads}}^{\mathrm{o}}\right)$ of adsorption. The Tafel constant values $\left(\beta_{\mathrm{a}}\right.$ and $\beta_{c}$ ) indicate that the extract is a mixed type with a cathodic component. Adsorbed species formed insoluble complex compounds when they came into contact with dissolved iron ions. The protection efficiencies reported using various electrochemical methods is consistent. Because this extract has no influence on Escherichia coli biological activity, it can be used safely in sanitation plants.

\section{References}

1. Eddy NO. Inhibitive and adsorption properties of ethanol extract of Colocasia esculenta leaves for the corrosion of mild steel in H2SO4. Int J Phys Sci. 2009;4(4):165-71.

2. Eddy NO, Odoemelam SA, Akpanudoh NW. Inhibition of the Corrosion of Zinc in 0.01-0.04 M H2SO4 by Erythromycin, Res. J Pure Appl Sci. 2008;4(12):1963-70.

3. Sultan AA, Ateeq AA, Khaled NI, Taher MK, Khalaf MN. Study of some natural products as eco-friendly corrosion inhibitor for mild steel in 1.0 M HCl solution. J Mater Environ Sci. 2014;5(2):498-503.

4. Selles C, Benali O, Tabti B, Larabi L, Harek Y. Green corrosion inhibitor: inhibitive action of aqueous extract of Anacyclus pyrethrum L. for the corrosion of mild steel in 0.5 MH2so4. J Mater Environ Sci. 2012;3(1):206-19.

5. Khadraoui A, Khelifa A, Boutoumi H, Hamitouche H, Mehdaoui R, Hammouti B, et al. Adsorption and inhibitive properties of Ruta chalepensis L. oil as a green inhibitor of steel in 1 M hydrochloric acid medium. Int J Electrochem Sci. 2014;9:3334-48.

6. Verma CB, Quraishi MA, Ebenso EE. Application of some oligopolymers as effective corrosion inhibitors for mild steel in $1 \mathrm{M} \mathrm{HCl}$ : gravimetric, thermodynamic and electrochemical analysis. Int J Electrochem Sci. 
7. Fouda AS, El-Hossiany A, Ramadan H. Calotropis Procera plant extract as green corrosion inhibitor for 304 stainless steel in hydrochloric acid solution. Zast Mater. 2017;58(4):541-55.

8. Fouda AS, Mohamed OA, Elabbasy HM. Ferula hermonis Plant Extract as Safe Corrosion Inhibitor for Zinc in Hydrochloric Acid Solution. J Bio-and Tribo-Corrosion. 2021;7(4):1-18.

9. Kamel MM, Fouda AAS, Rashwan SM, Abdelkader O. Paprika extract: a green inhibitor for mitigating carbon steel disintegration in $1 \mathrm{M} \mathrm{HCl}$ pickling solution. Green Chem Lett Rev. 2021;14(4):598-609.

10. Fouda AS, Al-Hazmi NE, El-Zehry HH, El-Hossainy A. Electrochemical and surface characterization of chondria macrocarpa extract (CME) as save corrosion inhibitor for aluminum in $1 \mathrm{M} \mathrm{HCl}$ medium. $\mathrm{J}$ Appl Chem. 2020;9(3):362-81.

11. Majidi L, Faska Z, Znini M, Kharchouf S, Bouyanzer A, Hammouti B. Synthesis and anticorrosive effects of epoxy-allylpulegols on steel in molar hydrochloric acid. J Mater Environ Sci. 2010;1(4):219-26.

12. Znini M, Cristofari G, Majidi L, Ansari A, Bouyanzer A, Paolini J, et al. Green approach to corrosion inhibition of mild steel by essential oil leaves of Asteriscus graveolens (Forssk.) in sulphuric acid medium. Int J Electrochem Sci. 2012;7:3959-81.

13. Chraibi M, Benbrahim KF, Elmsellem H, Farah A, Abdel-Rahman I, El Mahi B, et al. Antibacterial activity and corrosion inhibition of mild steel in $1.0 \mathrm{M}$ hydrochloric acid solution by M. piperita and M. pulegium essential oils. J Mater Environ Sci. 2017;8(3):972-81.

14. Belkhaouda M, Bammou L, Salghi R, Benali O, Zarrouk A, Ebenso EE, et al. Avogado Nuts Extract (ANE): An efficient Inhibitor of C38 Steel Corrosion in Hydrochloric Acid. J Mater Environ Sci. 2013;4(6):1042-51.

15. Fouda AS, Badr SE, Ahmed AM, El-Hossiany A. Chemical and electrochemical corrosion of a copper alloy in aqueous solutions by using morus alba extract as an eco-friendly inhibitor. Int J Corros Scale Inhib. 2021;10:1011-29.

16. Afia L, Salghi R, Bazzi E, Bazzi L, Errami M, Jbara O, et al. Testing natural compounds: Argania spinosa kernels extract and cosmetic oil as ecofriendly inhibitors for steel corrosion in $1 \mathrm{M} \mathrm{HCl}$. Int J Electrochem Sci. 2011;6(11):5918-39.

17. Salhi A, Bouyanzer A, Hamdani I, Chetouani A, Hammouti B, Znini M, et al. The use of essential oil and extract of Tetraclinis articulata as eco-friendly corrosion inhibitors of carbon steel in hydrochloric acid solution. Der Pharma Chem. 2015;7(2):138-47.

18. Fouda AS, El-Gharkawy ES, Ramadan H, El-Hossiany A. Corrosion resistance of mild steel in hydrochloric acid solutions by clinopodium actions as a green inhibitor. Biointerface Res Appl Chem. 2021;11(2):9786-803.

19. Halambek J, Berković K, Vorkapić-Furač J. The influence of Lavandula angustifolia L. oil on corrosion of Al-3Mg alloy. Corros Sci. 2010;52(12):3978-83.

20. Zerga B, Sfaira M, Rais Z, Touhami ME, Taleb M, Hammouti B, et al. Lavender oil as an ecofrindly inhibitor for mild steel in $1 \mathrm{M} \mathrm{HCl}$. Matériaux Tech. 2009;97(5):297-305.

21. Hussin MH, Rahim AA, Ibrahim MNM, Brosse N. The capability of ultrafiltrated alkaline and organosolv oil palm (Elaeis guineensis) fronds lignin as green corrosion inhibitor for mild steel in $0.5 \mathrm{M} \mathrm{HCl}$ solution. Measurement. 2016;78:90-103.

22. Sachinkumar Patil ${ }^{1}$ R, Rahul Shivaji Patil ${ }^{2}$, Godghate AG, Mentha Piperita Linn: Phytochemical, Antibacterial and Dipterian Adulticidal Approach, Int. J. Pharm. Pharm. Sci., 2016, 8(3): 352-355

23. Sroka Z, Fecka I, Cisowski W. Antiradical and anti-H2O2 properties of polyphenolic compounds from an 
aqueous peppermint extract. Zeitschrift für Naturforsch C. 2005;60(11-12):826-32.

24. Fouda AS, El-Wakeel AM, Shalabi K, El-Hossiany A. Corrosion inhibition for carbon steel by levofloxacin drug in acidic medium. Elixir Corros Day. 2015;83:33086-94.

25. Singh A, Singh VK, Quraishi MA. Inhibition effect of environmentally benign Kuchla (Strychnos nuxvomica) seed extract on corrosion of mild steel in hydrochloric acid solution. Rasayan $\mathrm{J}$ Chem. 2010;3(4):811-24.

26. Bentiss F, Traisnel M, Chaibi N, Mernari B, Vezin H, Lagrenée M. 2, 5-Bis (n-methoxyphenyl)-1, 3, 4oxadiazoles used as corrosion inhibitors in acidic media: correlation between inhibition efficiency and chemical structure. Corros Sci. 2002;44(10):2271-89.

27. Popova E, Sokolova S, Raicheva S, Christov M. 2, 5-Disubstituted 1, 3, 4-Oxadiazole Derivatives as Effective Extracts for the Corrosion of Mild Steel. 2M H3PO4 Solut Corros Sci. 2003;45:33-45.

28. Al-Sarawy AA, Fouda AS, El-Dein WAS. Some thiazole derivatives as corrosion inhibitors for carbon steel in acidic medium. Desalination. 2008;229(1-3):279-93.

29. Fouda AS, Shalabi K, E-Hossiany A. Moxifloxacin antibiotic as green corrosion inhibitor for carbon steel in $1 \mathrm{M} \mathrm{HCl}$. J Bio-and Tribo-Corrosion. 2016;2(3):1-13.

30. El Sherbini EEF. Effect of some ethoxylated fatty acids on the corrosion behaviour of mild steel in sulphuric acid solution. Mater Chem Phys. 1999;60(3):286-90.

31. Fouda AS, Azeem MA, Mohamed S, El-Desouky A. Corrosion inhibition and adsorption behavior of nerium oleander extract on carbon steel in hydrochloric acid solution. Int J Electrochem Sci. 2019;14:3932_48.

32. Fouda AS, Abd El-Maksoud SA, Belal AAM, El-Hossiany A, Ibrahium A. Effectiveness of some organic compounds as corrosion inhibitors for stainless steel 201 in $1 \mathrm{M} \mathrm{HCl}$ : experimental and theoretical studies. Int J Electrochem Sci. 2018;13:9826-46.

33. Fouda AS, Rashwan S, El-Hossiany A, El-Morsy FE. Corrosion Inhibition of Zinc in Hydrochloric Acid Solution using some organic compounds as Eco-friendly Inhibitors. J Chem Biol Phys Sci. 2019;9:1-24.

34. Fouda AS, Abdel-Latif E, Helal HM, El-Hossiany A. Synthesis and Characterization of Some Novel Thiazole Derivatives and Their Applications as Corrosion Inhibitors for Zinc in $1 \mathrm{M}$ Hydrochloric Acid Solution. Russ J Electrochem. 2021;57(2):159-71.

35. Fouda AS, Ibrahim H, Rashwaan S, El-Hossiany A, Ahmed RM. Expired drug (pantoprazole sodium) as a corrosion inhibitor for high carbon steel in hydrochloric acid solution. Int $\mathrm{J}$ Electrochem Sci. 2018;13:6327-46.

36. Motawea MM, El-Hossiany A, Fouda AS. Corrosion control of copper in nitric acid solution using chenopodium extract. Int J Electrochem Sci. 2019;14:1372-87.

37. Fouda AS, Eissa M, El-Hossiany A. Ciprofloxacin as eco-friendly corrosion inhibitor for carbon steel in hydrochloric acid solution. Int J Electrochem Sci. 2018;13:11096-112.

38. Fouda AS, El-Dossoki FI, El-Hossiany A, Sello EA. Adsorption and Anticorrosion Behavior of Expired Meloxicam on Mild Steel in Hydrochloric Acid Solution. Surf Eng Appl Electrochem. 2020;56(4):491-500.

39. Elgyar OA, Ouf AM, El-Hossiany A, Fouda AEAS. The inhibition action of viscum album extract on the corrosion of carbon steel in hydrochloric acid solution. Biointerface Res Appl Chem. 2021;11(6):14344-58.

40. Fouda AS, Ahmed RE, El-Hossiany A. Chemical, Electrochemical and Quantum Chemical Studies for Famotidine Drug as a Safe Corrosion Inhibitor for $\alpha$-Brass in HCl Solution. Prot Met Phys Chem Surfaces. 2021;57(2):398-411.

41. Khaled MA, Ismail MA, Fouda AES. Novel pyrimidine-bichalcophene derivatives as corrosion inhibitors 
for copper in $1 \mathrm{M}$ nitric acid solution. 2021;25314-33.

42. El Hamdani N, Fdil R, Tourabi M, Jama C, Bentiss F. Alkaloids extract of Retama monosperma (L.) Boiss. seeds used as novel eco-friendly inhibitor for carbon steel corrosion in $1 \mathrm{M} \mathrm{HCl}$ solution: Electrochemical and surface studies. Appl Surf Sci. 2015;357:1294-305.

43. Raja PB, Qureshi AK, Rahim AA, Osman H, Awang K. Neolamarckia cadamba alkaloids as eco-friendly corrosion inhibitors for mild steel in $1 \mathrm{M} \mathrm{HCl}$ media. Corros Sci. 2013;69:292-301.

44. Fouda AS, Abd El-Ghaffar MA, Sherif MH, El-Habab AT, El-Hossiany A. Novel anionic 4-tert-octyl phenol ethoxylate phosphate surfactant as corrosion inhibitor for C-steel in acidic media. Prot Met Phys Chem Surfaces. 2020;56(1):189-201.

45. Rauf A, Mahdi E. Evaluating corrosion inhibitors with the help of electrochemical measurements including electrochemical frequency modulation. Int J Electrochem Sci. 2012;7:4673-85. 